Gusarov I. V., Postgraduate Student Plekhanov Russian University of Economics Moscow, Russian Federation

DOI: https://doi.org/10.30525/978-9934-26-125-1-3

\title{
THE ROLE OF THE BANKING SECTOR IN FINANCING THE INNOVATIVE ECONOMIES OF THE BRICS COUNTRIES ${ }^{1}$
}

In the context of the economic crisis, an important role is assigned to the inflow of investments in financing innovative projects. Lack of funds makes it necessary to look for new financial sources.

Bank capital can be one of such additional sources. Despite the fact that, for example, the banks of the BRICS countries are the main holders of the capital of their countries, their financial resources are still insufficiently used to finance innovative development. The use of bank capital will increase the volume of investments required for the implementation of innovative projects.

Brazil. The ratio of the assets of the Brazilian banking sector to the country's GDP in 2020 was $149.4 \%$, i.e. Brazilian banks' assets exceeded GDP by almost 1.5 times. Consequently, banks have the potential to increase the volume of financing for innovative projects in the country's economy.

Lending to important innovation projects in the country is mainly handled by the state-owned Brazilian Development Bank (BNDES). The Bank provides long-term financing for the most important innovative projects related to the growth of the

${ }^{1}$ GRANT Plekhanov Russian University of Economics, Moscow, Russia \# 969 05.08.2020, \# 1232 08.10.2020 
national economy and the social sector. The bank's assets in 2020 decreased by 28\% against 2019 (to $\$ 141.7$ billion) [6], due to the coronavirus pandemic. But the rest of the banks are very weak in financing innovation.

The main directions of lending to Brazilian banks is the issuance of short-term commercial and consumer loans. Banks do not run the risk of engaging in long-term lending to innovative projects, despite the fact that there are enough funds for the implementation of risky projects of business angels in the country. The volume of bank lending to innovative activities in the country is about $20 \%$ of GDP, which is significantly less than in many developed countries, for example, 6 times less than in the United States, 3 times less than in Germany and Japan. The main issue of expanding bank lending in Brazil for the creation and implementation of innovative technologies remains the development by the government of the country of mechanisms to stimulate the attraction of bank capital.

Russia. The banking system of Russia has significant growth potential. Its liabilities are constantly increasing (in 2019 - by $1.4 \%$, in 2018 - by $11.1 \%$ ). By June 1, 2021, the funds increased to 60.7 trillion rubles (by 5.7\% against 2020). About half of these funds (44.4\%) in 2020 accounted for deposits and other attracted funds of individuals, $46.1 \%$ were funds of corporate clients, $5.4 \%$ funds of the public sector, $4.1 \%$ - other funds.

By March 31, 2021, bank assets increased to 107.7 trillion rubles, as a result of some economic recovery after quarantine due to the coronavirus pandemic, and an increase in lending [1]. Despite the fact that the volume of assets in foreign currency in ruble terms increased to 21 trillion rubles, banking assets in foreign currency decreased by $7.9 \%$ (to 304 billion dollars) [4]. Between 2000 and 2020, the ratio of the assets of the Russian banking sector to GDP increased 3.2 times and amounted to 
97.1\% in January 2021. The assets of the Russian banking sector exceeded the size of the consolidated state budget of the Russian Federation by 2.5 times. This indicates a significant potential for the participation of banking capital in the development of the country's innovative economy.

In June 2021, the loan portfolio of Russian banks amounted to 64.8 trillion rubles (their share in banks' assets was $60.2 \%$ ) [5]. However, it should be noted that against the background of the growth of the loan portfolio, loan delinquencies are increasing.

The increase in the debt burden was influenced by the increase in the interest rate on loans caused by the growth of the key rate for the year from $4.5 \%$ on June 22, 2020 to $5.5 \%$ on July 15, 2021 [3]. But on July 23, 2021, the Bank of Russia raised the key rate by 100 basis points to $6.5 \%$ [2], due to the fact that the Russian economy reached the pre-crisis level, as well as due to the growth of inflation (year on year to 6,5\%). On the one hand, the increase in the key rate will be aimed at reducing inflation to $4 \%$, but, on the other hand, it will affect the growth of interest rates on loans, including mortgage loans, and increase the debt burden.

Russian banks are still weakly involved in the innovative development of the country's economy. The volume of bank lending to innovative activities in the country in 2020 was $18 \%$ of GDP, which was significantly less than in many developed countries, for example, 7 times less than in the USA, almost 4 times less than in Germany, 3 times less than in Japan. The use of the banking capital of Russia will make it possible to obtain significant funds to finance the country's innovative development. To do this, it is necessary to identify the main directions, the introduction of which will make it possible to interest the country's banks in the implementation of long-term 
lending to the innovation sector. In resolving this issue, the central place should be occupied by the government of the country. In addition, in Russia, there is a weak link between scientific research and innovative development. The commercialization of research and technological development results is insufficient.

India. Despite the fact that the share of Indian banks in financing the country's innovative projects is one of the most significant among the BRICS countries (49\% of GDP), India lags behind the United States by 2.6 times, from Germany by 1.3 times. from Japan - 1.2 times. Consequently, India, like other BRICS countries, needs to pay more attention to creating a system of encouraging banking activities in lending to an innovative economy. Despite the fact that the Indian banking system pays attention to financing innovation, the country's bank lending line lacks specialized, structured loan products that would be focused on financing innovation. In addition, in many small banks there is a lack of highly qualified specialists who can professionally assess the importance and effectiveness of innovative projects of bank clients.

China. The main directions of bank financing in China are investments in the development of clean technologies, alternative energy, biotechnology, information technology, new materials, new types of vehicles, modern equipment (it is planned to invest up to $\$ 18$ billion). About half of this amount will be invested by the Chinese government in the development of new technologies to prevent harmful anthropogenic impact on the environment, more than a third - in the development of alternative energy sources, a tenth - in the creation of smart grids.

The share of Chinese banks in lending to the country's innovative developments is the largest among the BRICS 
countries (55\% of GDP), but nevertheless, according to this indicator, China lags behind the United States by 2.3 times, from Germany - 1.2 times, from Japan - 1.1 time. This suggests that China, like other BRICS countries, is interested in increasing the volume of attracting bank capital to finance innovative developments. However, the government of the country has not yet paid due attention to the solution of this issue. In addition, Chinese banks, fearing to finance long-term risky innovative projects, are not interested in structuring credit products to reduce possible risks, and also seek to provide short-term loans, rather than long-term ones, which can increase credit risks.

The volume of lending by South African banks to innovative developments in the country amounted to $10 \%$ of GDP in 2020, which is almost 13 times less than in the United States, 7 times less than in Germany, 6 times less than in Japan. South African banks are afraid to participate in lending to risky innovative projects. They prefer to provide short-term rather than long-term loans. The government of the country does not pay due attention to the creation of incentive measures to develop the interest of banking structures in innovative financing.

To attract the banking capital of the BRICS countries to finance innovation processes, it is necessary: a) provide state support to banks in financing highly risky innovative projects; b) ensure the interest of banks in financing risky venture projects by providing incentives and tax preferences; c) the use of special investment products by banks to finance innovative companies; d) creation by banks not only of various programs for providing loans, but also risk management programs, programs for attracting resources for the implementation of innovative projects. 


\section{References:}

1. Analytical balance sheet of the banking sector. Central Bank of the Russian Federation. URL: https://www.cbr.ru/Collection/Collection/File/ 35412/analytical_review_bs-2021-1.pdf (accessed 13 July 2021).

2. The Bank of Russia raised the key rate to $6.5 \%$. URL: https://tass.ru/ekonomika/11971691 (accessed 23 July 2021).

3. Macroeconomic indicators of the banking sector of the Russian Federation. URL: http://www.cbr.ru/statistics/bank_sector/review/ (accessed 13 July 2021).

4. Structure of the banking sector loan portfolio. URL: http://www.cbr.ru/statistics/bank_sector/review/ (accessed 13 July 2021).

5. 2019 Annual Results Announcement. Bank of China Limited. URL: https://pic.bankofchina.com/bocappd/report/202003/P0202003275521 90406499.pdf (accessed 13 July 2021).

6. List of Major Banks in Brazil - Top 10 Brazilian Banks 2020. URL: https://www.advratings.com/latin-america/top-banks-in-brazil (accessed 13 July 2021). 